\title{
ルクソール西岸・マルカタ王宮内の「アマルナ型住宅 $\mathrm{A} 」$ に関する考察 \\ 古代エジプト・アマル十型住宅に関する建築学的考察 2 \\ “THE AMARNA-TYPE HOUSE A" IN THE MALQATA PALACE \\ AT THE WESTERN BANK OF LUXOR
}

Architectural studies on the Amarna-type house in ancient Egypt 2

\author{
遠藤孝治* \\ Takaharu ENDO
}

Three independent houses preserved at the Malqata Palace have overall similarities with the standard Amarna-type houses, nevertheless they present some architectural differences related to the official building characters, and the simpler details possibly show the tentative phases before the completion of this house-type. A careful study of the remaining brick pavement of the central hall in "Malqata-House A" concluded that a large stone dais for the master had been placed on the rear wall and that the roof of this hall had been supported by two columns resting on the edges of a stone dais, or more appropriately that it had been spanned by one single wood beam without any columns.

Keywords: Ancient Egypt, New Kingdom, Amarna-type House, Malqata Palace, Thebes 古代エジプト、新王国時代、アマルナ型住宅、マルカタ王宮、テーベ

\section{1.はじめに}

古代エジプトの都市遺跡の大部分は、現在の住宅地または農耕地 の下に埋もれたままであり、ことさら住宅は石造建築に比べて耐久性 の低い日乾棟瓦で主に造られたために残存状態が悪く、それ故にこの 文明の住宅建築について、これまで十全な研究がなされずにいるとい うことはすでに拙稿1で述べた通りである。拙稿では、こうした状況 の中で最も多数の住宅遺構が残るアクエンアテン王 (紀元前約 1352 〜 1336 年頃) が築いた都市アマルナのいわゆる「アマルナ型住宅」 に焦点を当て、未だ不明なこの住宅形式の成立過程 ${ }^{2}$ を探る上で、同 住宅形式に類似した例として指摘されてきた他地域のいくつかの住宅 遺構や、墳墓や神殿の壁面に描かれた絵画資料としての住宅の既往解 釈について再検討を試み、ルクソール西岸に位置するアメンヘテプ 3 世のマルカタ王宮内に建てられた 3 軒の住宅が、古代エジプト新王国 時代の高官のための有名な住宅形式である「アマルナ型住宅」の初例 として現在知られる唯一確かな遺構であることを明らかにした。

マルカタ王宮については、早稲田大学エジプト学研究所が1985年 から再調査 (元調査隊長 : 故渡辺保忠・早稻田大学理工学部教授 (当 時)、現調查隊長 : 吉村作治・同大学人間科学部教授）を開始してお り、主王宮の内部から出土した多量の彩色画片の整理作業が現在継続 中である3。王宮内に残存する 3 軒の横に並んだ独立住宅A、B、Cは、
アマルナ型住宅の平面構成の基本的原則に従って、住宅の全体平面が ほぼ正方形の形状を呈し、平面を 3 分割して中央に住居内で最も広い 部屋を配し、入口を北側に持ち、主人の私室となる寝室を南側に備え ている（図 1)。これらの住宅遺構のさらなる建築的特徍を把握する ために、1995年 12 月から 1996 年 1 月におこなわれた早稲田大学調 查隊のルクソール調查の際に、建築班は 3 軒のうちで残りが良い住宅 Aの最も重要な部屋と見做される中央の広間とその手前の控えの間な どの床面上に堆積した砂を除去し、床敷き煉瓦の記録をおこなった4。 調査の結果、北側の控えの間から中央広間へと登るステップが存在す ることや、中央広間に柱が立てられた痕跡が全く認められないこと、 また同室の南壁に接してかつて大型の石版を設置したらしき長方形の 搳みが残ることなどが明らかとなった。これらの諸点は、都市アマル ナに残存する通常のアマルナ型住宅と比べると特異であり、王宮内に 建てられた住宅Aの建築的特徵として注目される。本稿では、マルカ 夕王宮内の住宅Aについて、調査結果を基に細部に見られる典型的な アマルナ型住宅との相違点を整理するとともに:この住宅の中央の主 要広間について復原案を考察することとしたい5。

\section{2. マルカタ王宮内にある「アマルナ型住宅 A」の現況報告}

拙稿でも述べたようにマルカタ王宮内に残る 3 軒のアマルナ型住宅 
は、建材として用いられた日乾煉瓦にアメンヘテプ 3 世の王名スタン プが押されていることからも、テーベからアマルナへの遷都以前に造 られたことが明らかであり、同住宅形式の祖形を示すものとして重要 である。都市域に建てられたアマルナ遺跡の住宅は、穀物倉庫や調理 場、庭園などの付属要素を住宅の周りの敷地内に個々に保持している が、王宮内にあるマルカタの 3 軒の独立住宅にはこれらは存在しな W。

図 2 は、3軒の住宅のうち最も残存状況が良好な住宅Aの詳細平 面図と断面図であり、覆土の除去が終了した部屋の床敷き棟瓦を示し たものである。後述する各部屋の番号については、同じ図の右下にあ
る模式図に従う。玄関に相当する部屋 1 の戸口（図 2-a）には床面 に上るための煉瓦造のステップの一部が残存していたが、階段やス ロープによって導入される玄関ポーチを備える典型的なアマルナ型住 宅と比べると、これは非常に簡素な造りである ${ }^{6}$ 。玄関ポ一チを備え ていない点は隣接する住宅 $\mathrm{B}$ と $\mathrm{C}$ 同様である。部屋 1 から部屋 6 〜 7 に続く戸口の位置は意図的にずらされており、古代エジプトの住宅 建築において頻繁に認められるような鈎型の導入経路を成している7。 中央広間 (部屋 9 ) への戸口の手前には煉瓦を並べて造られた 1 段の ステップがあり、部屋 7 からはおよそ $10 \mathrm{~cm}$ 上るようになっていた が、これら 3 軒の住宅が立地するところの自然地形は北東から南西に

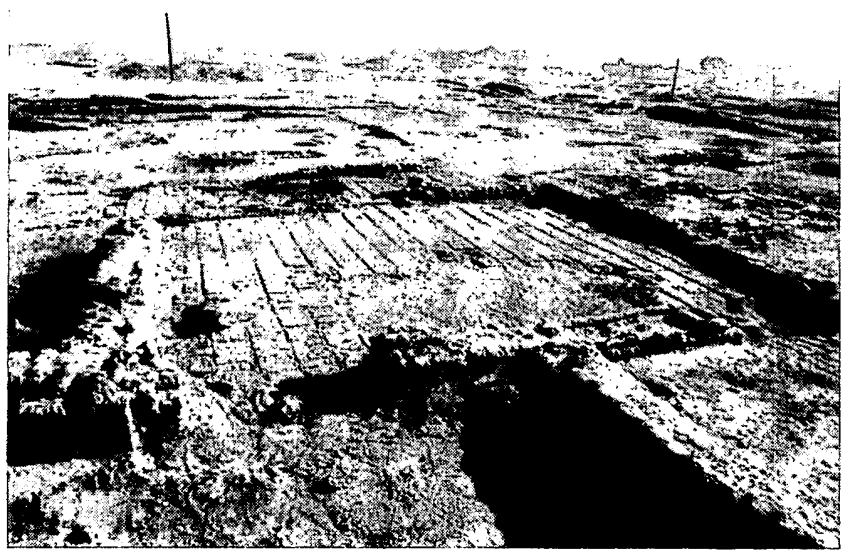

写真 1 マルカタ王宮内のアマルナ型住宅 Aの現況 南西から見る（写真は早稲田大学理工学部建築史研究室所蔵）

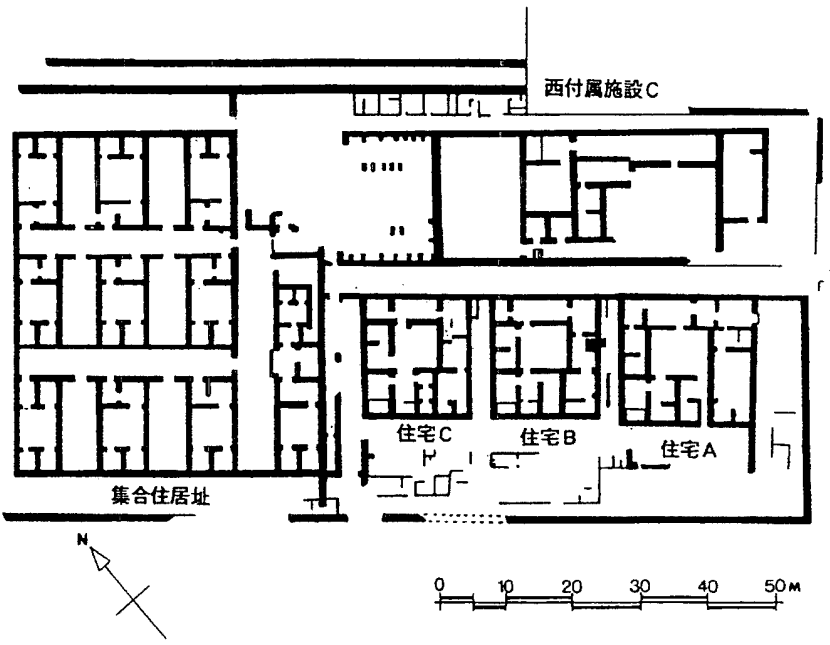

図 1 マルカタ王宮西住居址 平面图

Lacovara: The New Kingdom Royal City (London 1997), Fig. 40 を基に 1 部筆者改訂

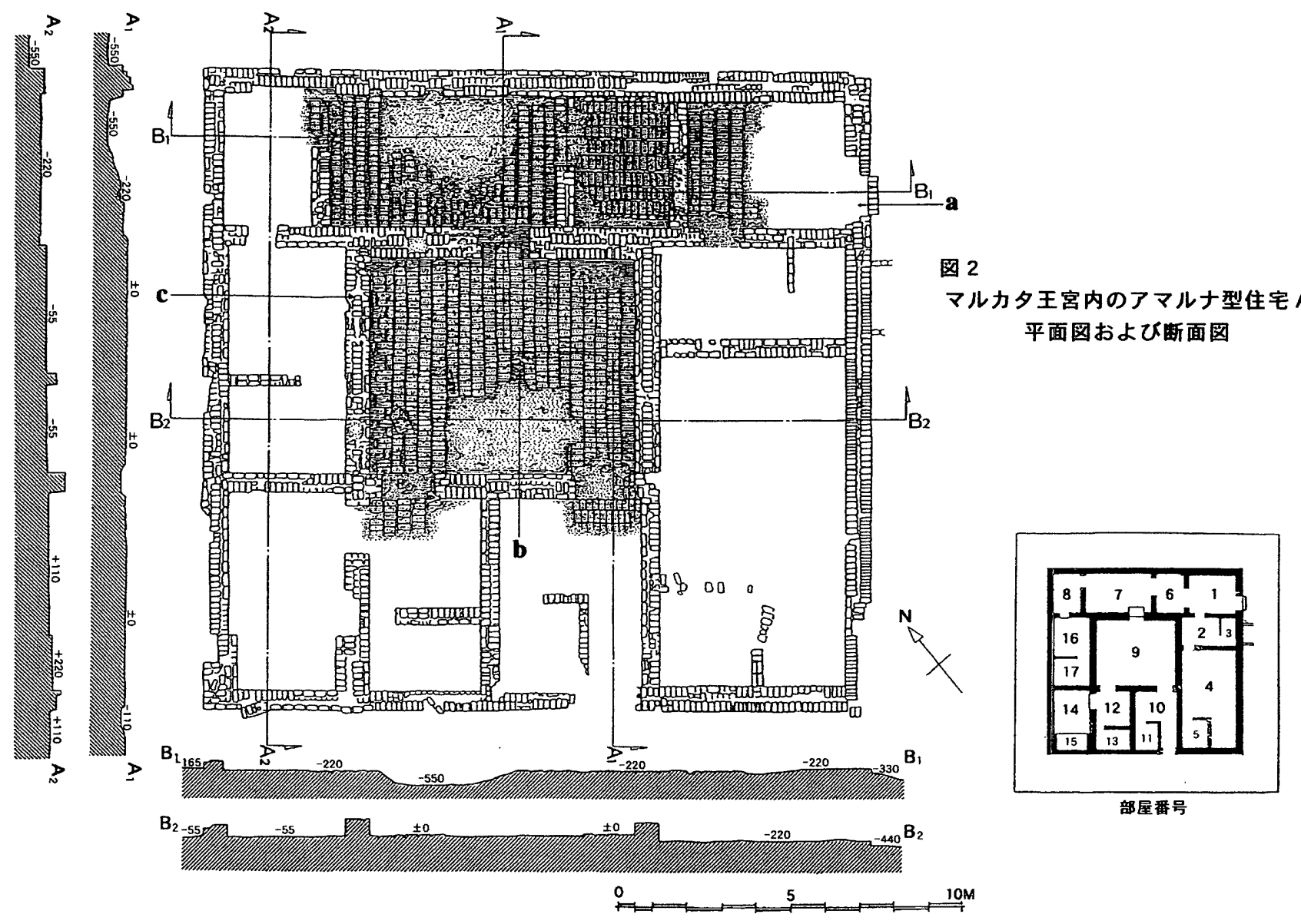


かけてゆるやかに上昇しており、これに対応させつついくつかの部屋 ごとに床高さを変化させる工夫がなされていた。住宅では入口から奥 に入るほど私的性質の高い部屋が配されており、その秩序を床高さの 調整で視覚的にも明瞭に表現しているという点は、同時代の神殿建築 で奥の聖域に向かうほど床を暫時上昇させて、より一層と神聖さを高 めるという手法と共通と考えられる。このような工夫は都市アマルナ に残る住宅遺構ではなされていない。

古代エジプトの住宅建築の場合、一般に柱は木で造られて石製の 基礎の上に設置された。柱礎石は床棟瓦を敷き並べる前に据えられた ので、たとえ礎石だけが再利用のために収奪されたとしても、円形の 穴が床面に残存することになり、遺桡ではこれを頼りにして当初の柱 の位置を確認することが可能である。都市アマルナに築かれた規模の 大きなアマルナ型住宅において北の控えの間や中央広間には柱が必ず 立てられているが、これらとほとんど同じ規模である住宅 $\mathrm{A}$ の場合 では、いずれの部屋においても柱礎石の痕跡が 1 つも見つかっておら ず、特異である。

中央広間南壁の手前では、棟瓦が敷かれていない浅い長方形の搳 みが観察され、またこの注みの縁辺部では石灰質のモルタルが残存し ていた。長方形の窪み自体の大きさは約 $3.5 \times 2.1 \mathrm{~m}$ であり、中央広 間内でかなり大きな面積を占める（写真 2 )。痕跡を総合すると、か つてこの位置に石版が貼られており、再利用のために全て収奪された という可能性が指摘される。この解釈は、周辺の床面においておそら く石版を剥がそうとしたときに用いたと思われる工具の摖痕が認めら れたことからも補強される。同じく中央広間のほぼ中央では直径約 $17 \mathrm{~cm}$ 、樑さ約 $14 \mathrm{~cm}$ の小さな円形の穴が見つかった（図 $2-\mathrm{b}$ 、図 3)。この穴は通常約 $60 \mathrm{~cm}$ から $1 \mathrm{~m}$ 弱の径を有する柱礎石のための穴 としては明らかに小さすぎであり、大きさと室内の位置から考えると エジプトの住宅遺構の広間において頻繁に認められる冬または早朝に 暖を取るための炉の跡である可能性が高い ${ }^{8}$ 。

中央広間の西壁北側の下 (図 $2-\mathrm{c}$ ) では石灰岩製の戸口が煉瓦 で完全に埋め潰されており、ある時期に改変がなされたことが窥われ た。広間の東壁側にも戸口が全く存在しておらず、この結果、中央広
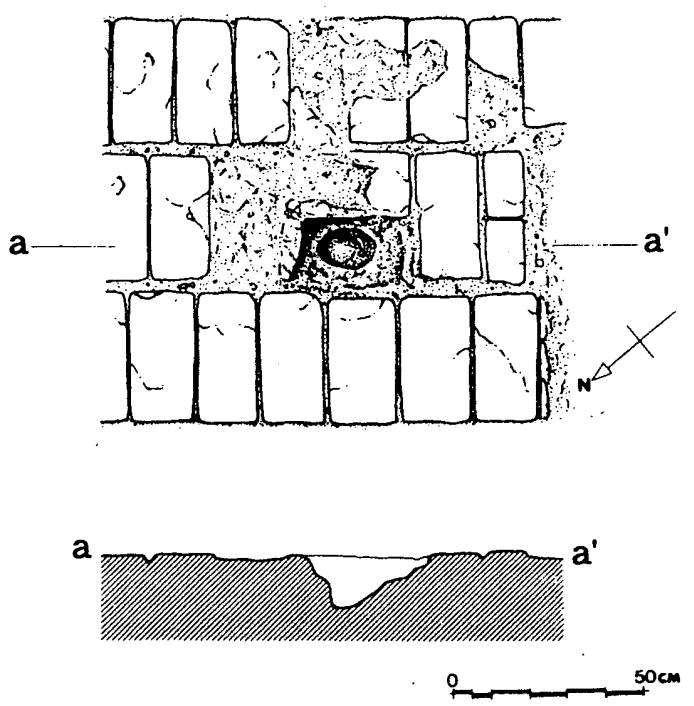

图 3 マルカタ王宮住宅A 広間の床面に穿たれた小穴 平面图およひ断面图

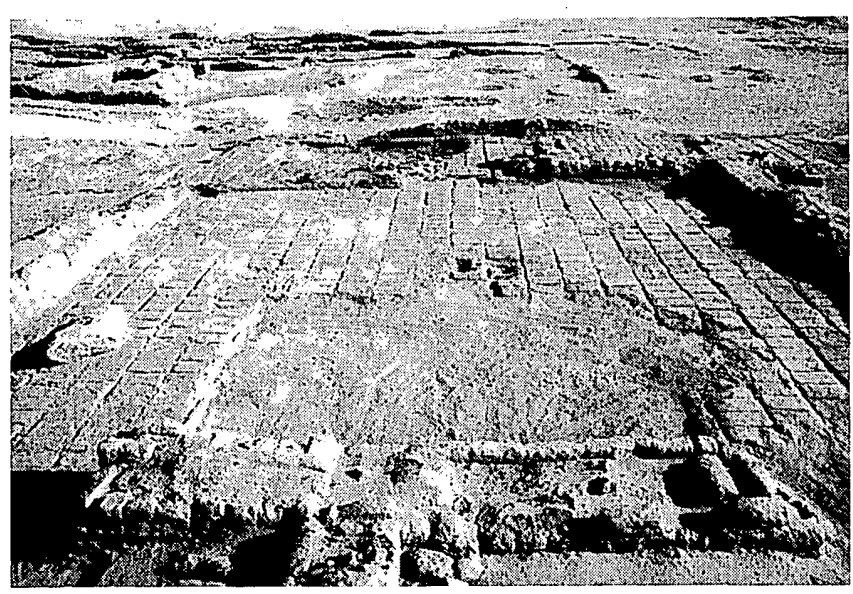

写真2 マルカタ王宮住宅 Aの中央広間に見られる長方形の篗み跡 南西から見る (写真は早稲田大学理工学部建筑史研究室所藏)

間からは東西にあるどちらの部屋にも行き来することができなくなつ ている。都市アマルナに残存する大型のアマルナ型住宅の中央広間で 頻繁に見られる扉を模した壁㓱装飾や、通常広間に隣接する部屋に設 けられた屋上または 2 階への階段、住宅の後方部における家族のため の小広間は、住宅Aには存在しなかった。

住宅 $\mathrm{A}$ を構成する壁体は、外壁と中央広間を取り囲む壁体、並び に寝室の部分において、他の箇所よりも厚く施工されている。これに は住宅の骨格となる部分を構造的に強化する意図があったと推測さ れ、特に中央広間では天井近くに恝を備えるために周囲の部屋よりも 壁を高く立ち上げる必要があったという点も考慮された可能性が高 い。また一方で、日乾煉瓦造の比較的厚い壁体は強烈な太陽熱に対し て一種の絶縁体の役割を果たすことが指摘されており 、室内環境を 快適に保つための工夫も兼ねていたと考えられる。

\section{3. 典型的なアマルナ型住宅との相違点}

マルカタ王宮内の住宅 $\mathrm{A} \sim \mathrm{C}$ が、住扂の基本的骨格においてアマ ルナ都市遺跡に残存する典型的なアマルナ型住宅の平面構成と合致す ることはすでに拙稿で指摘した通りであるが10、以上に述べた現況か ら窥える紼部に目を向けると、以下に列挙するようないくつかの建築 的な相違点も抽出される (図 4 参照)。

\section{住宅 $A \sim C$ に共通する相違点}

・斜路または階段でアプローチされる玄関ポーチが存在しないこと ・玄関側から奥の部屋に向かって床高を上け゚ていること

・款物倉庫や調理場などの生活設備が住宅の周りにないこと

\section{住宅 Aに関して付け加えられる相连点}

・中央広間の南側に大きな長方形の石版が備えられていたこと

・中央広間に扉を模した壁俞装飾がないこと

・中央広間から東西の諸室へと直接行き来することができないこと

・2 階または屋上への階段が存在しないこと

・住宅の後方部に家族のための正方形平面の小広間がないこと

・各部屋に柱が用いられた跡が認められないこと

これらの相違点の多くについては、マルカタ王宮内の住宅 $\mathrm{A} \sim \mathrm{C}$ 

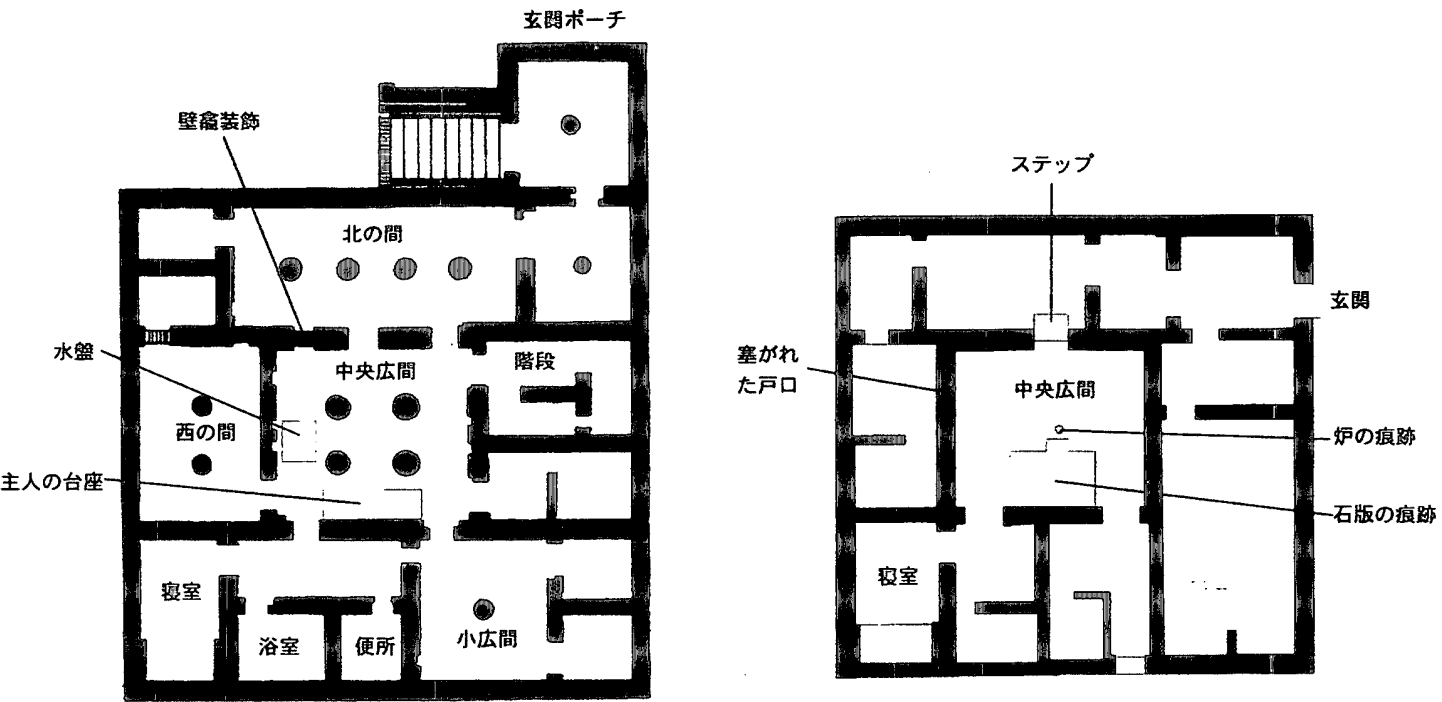

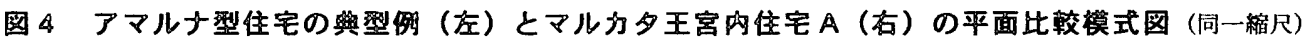
左図は Borchardt and Ricke: Die Wohnhäuser in Tell el-Amarna (Berlin 1980), Plan 23: P47.19 を基に筆者作成

が、都市域に建てられたアマルナの貴族のための独立住宅の場合と異 なって、王宮施設内に設けられた建物であるということに関係すると 思われる。これら３軒の独立住宅が、誰のために何の目的で建てられ たものであるかは具体的には明らかではないがい、王宮内で 3 軒が整 然と並び立つ様子からは公共的な性格が窥われる。都市アマルナの独 立住宅では、塀に囲まれた敷地内に穀物倉庫や調理場などの生活設備 が備えられ、主人とその家族、並びに使用人など数多くの人が屋敷内 に定住した。彼らのための生活空間や寝室が必要不可欠であったた め、マルカタ王宮内の住宅 $\mathrm{A} \sim \mathrm{C}$ の場合とは異なって、住宅の後方 部に家族のための私的な小広間が配備され、2 階または屋上も居住空 間として広く利用された ${ }^{12}$ と考えることが可能である。また例えば、 都市アマルナの大アテン神殿の近傍に、神殿に仕えるパアネヘシィと いう神官のための公暗があり（図 5 )、この遺構の場合も中央に大き めな広間を配するなどの点でアマルナ型住宅の平面構成との類似性を

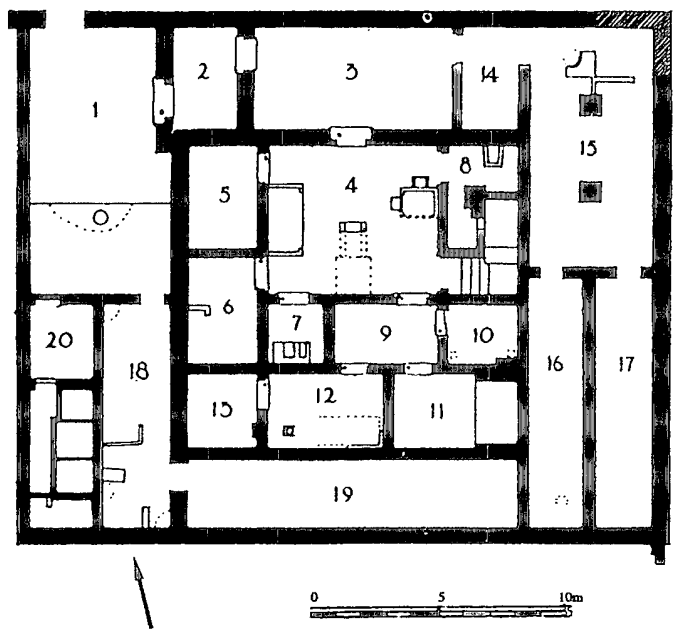

图 5 神官パアネヘシィの公酣平面图 Pendlebury: The City of Akhenaten III (London 1951), Pl. XIより
示しているが、住宅Aと同様に家族のための小広間は不必要であった ので、そのような部屋を住宅の後方部に備えていないと考えられる。 加えて、玄関ポーチがないことや、各部屋に柱が多用された様子が 見られないこと、中央広間における装飾的要素の 1 つである壁䧻が設 けられていないことなど、マルカタ王宮の住宅Aは典型的なアマルナ 型住宅と比べて全般的に欠如している要素が多いということも指摘さ れる。これら緒要素の欠如については、全て建物の用途に起因するだ けでなく、次代の都市アマルナで 1 つの住宅形式として完成される直 前のいくぶんか飾り気の少ない初期的な姿を示していると考えること も可能であろう。

一方、住宅Aにおいて、中央広間に柱の痕跡が見当たらず、入口側 から向かって正面に異様な大きさの石版が備えられていたことは、都 市アマルナに残る典型的なアマルナ型住宅と比べて特異な点として最 も注目される。古代エジプトの住宅において室内に置かれる石製品 は、手洗いまたは清めのための水盤が最初に思い起こされるが、住宅 A の場合、石版が存在したと考えられる長方形の濯みの大きさが約 $3.5 \mathrm{~m} \times 2.1 \mathrm{~m}$ もあり、水盤の通例と比べるとあまりにも大きいため別 の解䣋が求められる。また、住宅Aの中央広間のスペンは最短でも約 $6.3 \mathrm{~m}$ あり、同規模の典型的なアマルナ型住宅の場合では中央広間に 必ず 2 本か 4 本の柱が立てられている13にもかかわらず、広間床面に 柱が立てられた跡が全く見られないことは、この部屋の当初の姿を復 原するに当たって問題である。住居内で最も重要な部屋と見做される 中央広間の解釈は慎重を期すべきであり、これらの建築的に重要な問 題については、通常の住宅遗構だけでは十分な類例が認められないの で、以下においてアマルナ遺跡に残る特別な広間を有するいくつかの 遺構例にも視野を広げて、詳しく考察を巡らせることとしたい。

\section{4.アマルナ遗跡における特敨的な広間の例 4.1. 窣相ナクトの住宅}

南市街に残存する莘相ナクトの住宅は、約 $29 \times 26 \mathrm{~m}$ の平面規模を 有し、屋内に 2 つのさめな寝室を配するなど、アマルナでは最大級 


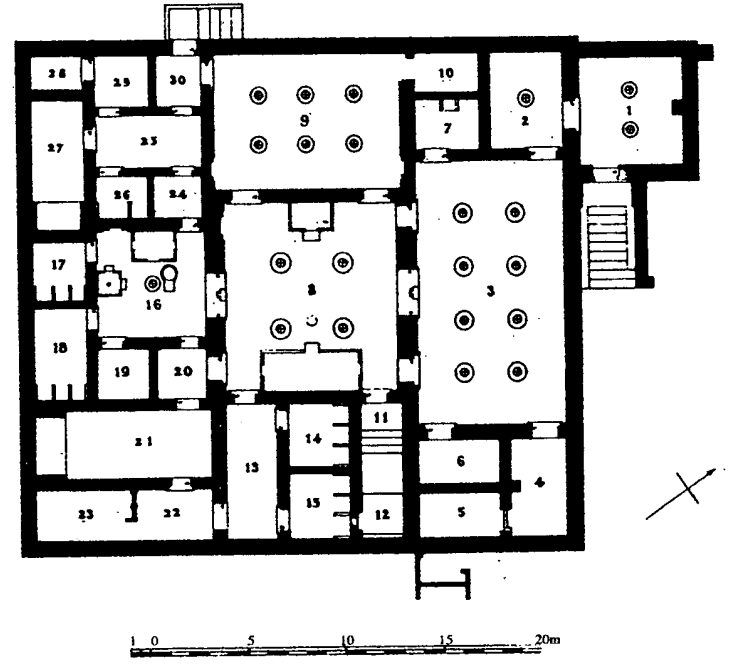

図 6 宰相ナクトの住宅 平面图

Peet and Woolley: The City of Akhenaten I (London 1923), P1. III より

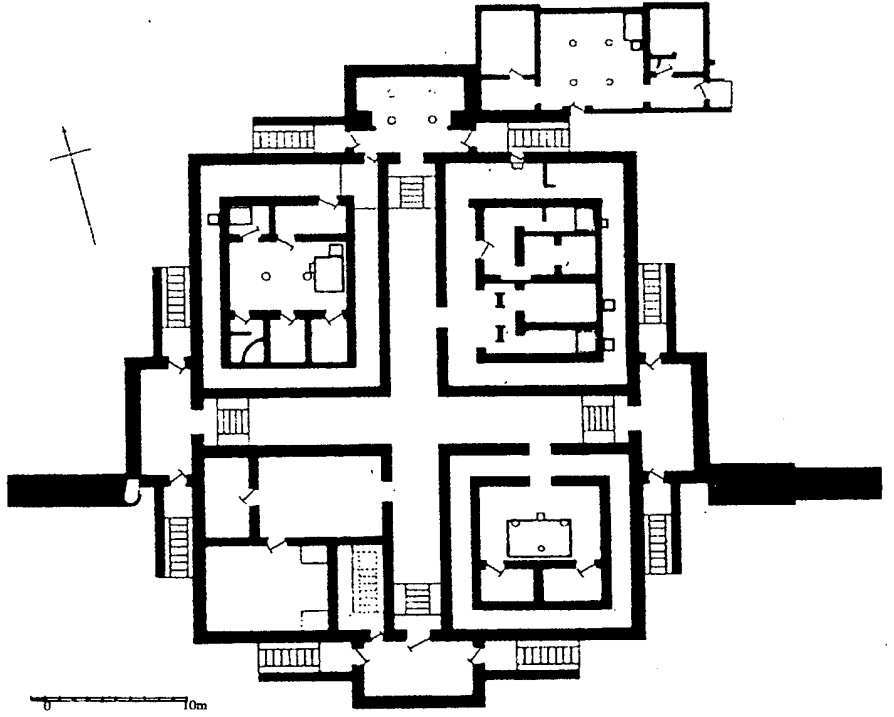

图 7 外国人朝貢の間 平面图

Pendlebury: The City of Akhenaten III (London 195I), PI. Xより

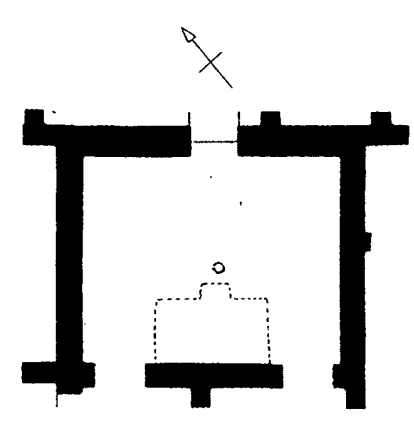

1. マルカタ王宮住宅 A

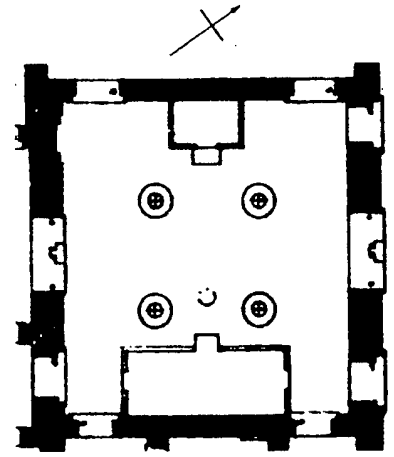

2. 辛相ナクトの住宅

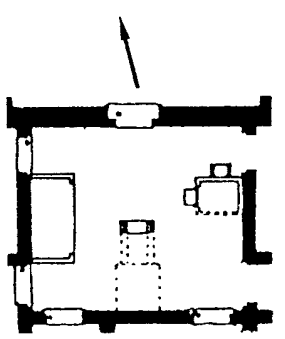

3. 神官パアネヘシィの公邱

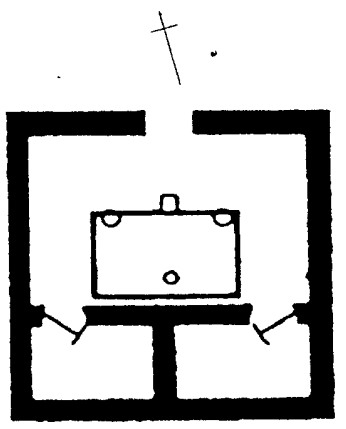

4. 外国人朝貢の間

図 8 中央広間の比較（縮尺は全て $1 / 300 ）$

の住宅遺構の 1 つとして有名である（図 6) ${ }^{14}$ 。約 $8 \mathrm{~m}$ 四方の中央広 間には、 2 列 4 本の柱が立てられ、西壁側には大きさ約 $2 \times 1.3 \mathrm{~m}$ の 石製の水盤、東壁側には大きさ約 $5.1 \times 2.1 \mathrm{~m}$ の主人のための煉瓦造 の台座が設置されている。台座のすぐ手前には暖をとるための小さな 円形の炬が備えられていた（図 8.2）。

\section{2. 神官パアネヘシィの公哂}

中央市街にある大アテン神殿の南外側に残存する神官パアネへ シィの住宅は、約 $17 \times 14 \mathrm{~m}$ の平面規模を有する住宅部分とそれを取 り囲む長方形の細長い倉庫群で構成される（図 5 )。パアネヘシィは 他に南市街にも大きな住宅を持っており、発握をおこなったペンドル ベリィによれば、この住宅はパアネヘシィが神殿に勤続する際、数日 の間、宿泊するために利用された公䄮であると考えられている15。約 $6.5 \times 5.5 \mathrm{~m}$ の中央広間には、西壁側に大きさ約 $2.7 \times 1.3 \mathrm{~m}$ の台座、 東壁側には約 $1.6 \times 1.1 \mathrm{~m}$ の石製の水盤が設置されている。さらに南 壁側には約 $2.7 \times 1.4 \mathrm{~m}$ の範囲でモルタルの痕跡が認められ、同位置 で出土した石材断片の復原から、かつては高さ約 $1.5 \mathrm{~m}$ の石製の祭壇 が設けられていたことが推定されている（図 8.3）。広間のスパンは、 マルカタ王宮の住宅 $\mathrm{A}$ と同様にかなり大きめであるが、柱は 1 本も
立てられていない。

\section{3. 外国人朝貢の間}

外国人朝貢の間 (The Hall of Foreign Tribute) とは、大アテン神殿の 北外壁にまたがって建てられた施設であり、アマルナの岩窟墓内に描 かれた壁画資料を基にした考察から、第 1 発掘者のフランクフォート によってこの名が付けられている ${ }^{16}$ 。平面プランは中央に走る十字の 通路によって4つの区画に分割されており（図 7)、このうち南東の 区画にある広間において極めて大きな水盤（約 $4.5 \times 2.7 \mathrm{~m}$ ）が置か れている点に注意が惹かれる(図8.4)。広間の大きさは約 $8.5 \times 5.2 \mathrm{~m}$ であるが、ここでの水盤は部屋幅の中央に達するほどに大きく、屋根 を支えるための 2 本の柱の基礎石が水盤の隅に載せられていた。

\section{5. 住宅 A 中央広間の復原案についての考察}

\section{1. 中央広間の石版について}

すでに述べたように、古代エジプトの住宅の室内には、必ずという わけではないが、手洗いまたは清めのための石製の水盤が備えられる ことが多い。都市アマルナでは、約 30 戸の住宅遺構において中央広 間にこうした水盤が残存するが、それらの大きさを表に整理すると、 

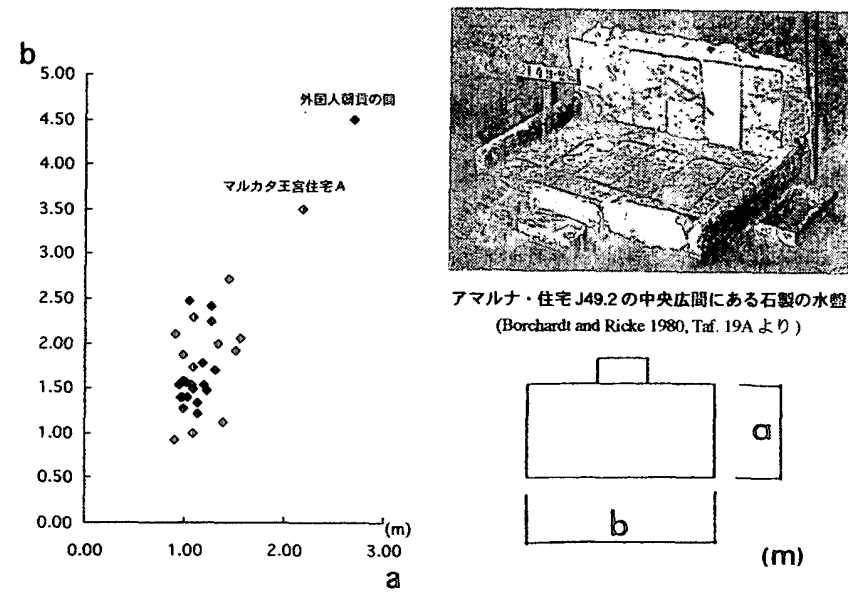

アマルナ・住宅 J49.2 の中央昿間にある石短の水整 (Borchardt and Ricke 1980, Taf. 19A 上り)
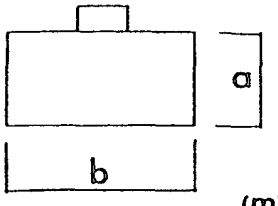

(m)
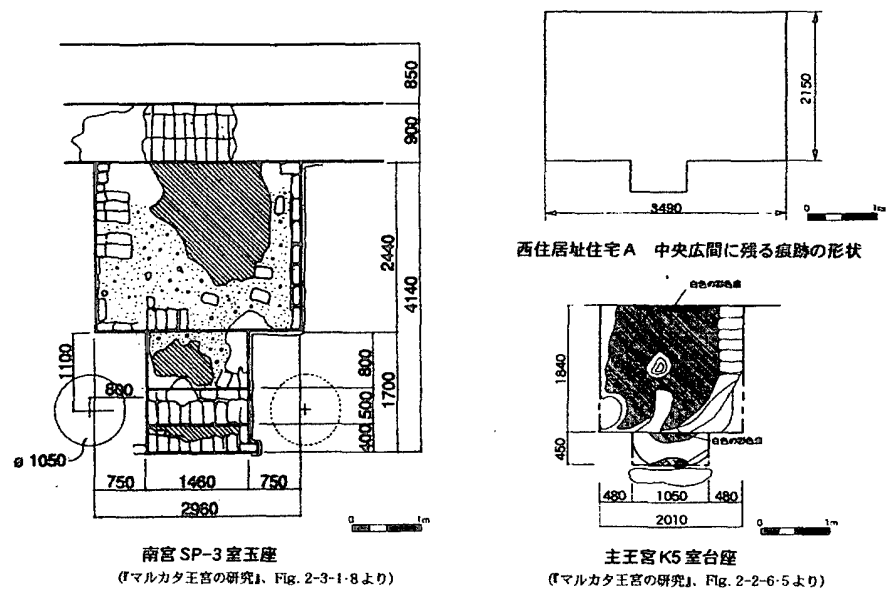

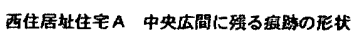

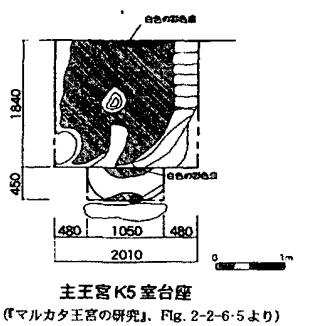

表 1 中央広間に設置された水盤の大きさについて

住宅の規模にかかわらず約 $1.5 \times 1 \mathrm{~m}$ 前後という大きさが標準的であ ることが分かる（表 1)。従って、通常の住宅遺檕ではない外国人朝 貢の間の例のように特殊な場合があるものの、住宅Aに見られる長 方形の涳みは水盤としては想定することが困難な大きさと言わざるを 得ない。

一方、この長方形の窪みの手前に観察された円形の小穴にも目を 向けるならば、ナクトの住宅の中央広間で見られるような家の主人の ための台座とその手前に備えられた円形の炉との位㯰関係が極めて合 致する点が注目される（図6、図8.1、図8.2）。住宅Aにおける問題 の長方形の寉みは、マルカタ王宮南宮にある玉座 (約 $2.9 \times 2.4 \mathrm{~m})$ に 匹敵する大きさであり (図 9)、ナクトの住宅のような大きな台座(約 $5.1 \times 2.1 \mathrm{~m})$ の存在も視野に入れると、台座としてならば必ずしも あり得ない大きさではないと考えられる。ここで古代エジプトの住宅 建築における台座は大抵、媡瓦造であるという問題が残るが、20世 紀初頭にマルカタ王宮の部分的発掘をおこなったタイトゥスは主王宮 内E室の玉座が日乾煉瓦を核として砂岩を被覆する造りであったと報 告しており ${ }^{17}$ 、また例えばマディーナト・ハーブ地区のラメセス 3 世 記念神殿内に残存する付属王宮ではアラバスタ一製の台座が玉座とし て用いられている18。従って、住宅Aもこれらと同様に石製の台座が 備えられていた可能性を十分に疑って良いであろう。逆に、たとえ石 製だという理由から台座の可能性を排除したとしても、パアネへシィ の公邸で見られるような祭壇や、または、異例な大きさの水盤を住宅 Aに想定した場合、手前に存在する炉と思われる円形の小穴との関連 についての説明が困難となってしまう。また、水盤は必ずしも住居の 中央広間内に備えられたものではないため、これがないと考えても不 思議なことではない。

\section{2. 中央広間の天井支持構造について}

次に広間の天井支持構造に関してであるが、アマルナに残存する 多数のアマルナ型住宅において中央の広間が露天の中庭として利用さ れた例は皆無であり、上で結論したように住宅Aには主人の台座や 炉が備えられていたことも考慮すると、ここで中央広間に屋根が存在 しなかったという可能性は極めて低い。古代エジプトの住宅研究者の 1 人であるアーノルドは、一般に古代エジプトの住宅建築において、
ヤシ材などの梁を架け渡した上に木の枝などを束ねて蒀き、泥を染つ て仕上げるという屋根搆造が採られる場合には、 $3.5 \mathrm{~m}$ 程のスパンが 標準であったと解説しており ${ }^{19}$ 、部屋のスパンが約 $6.3 \mathrm{~m}$ もある住宅 Aの中央広間には、どこかに柱を想定する必要があるように思われる が20、上述したように床敷きの煉瓦には柱礎石の跡を全く見つけるこ とができない。状況証拋が不足しているためこの部屋に柱が存在した かどうかは不明と言わざるを得ないが、仮に柱が立てられていたとす れば、1つの可能性として、外国人朝貢の間の場合のように、南壁に 接して設置された大きな石製の台座の隅に柱が立てられて屋根を支持 していたと考えられ、現在はこの台座の石が全て取り去られたために 柱の痕跡が見つからないと推測される。ただし、この復原案の場合、 柱が広間幅の中央に配置されないという点が、他の日乾棟瓦造の住宅 遺構には決して見ることのできない矛盾として残る。

もう1つの可能性は、この部屋にはもともと柱が存在しなかったと いう仮定である。先に述べたパアネヘシィの公期は中央広間のスパン が5m以上もあるにもかかわらず、柱を立てずに屋根をかけていたこ とがクラークによる復原透視図にも示されており（図 10） ${ }^{21}$ 、また住 宅Aと同じ新王国時代の文字史料からトトメス 3 世王の造船所におけ る資材の支給記録を見ると、最大で長さ 30 キュービット(約 $15.75 \mathrm{~m}$ )

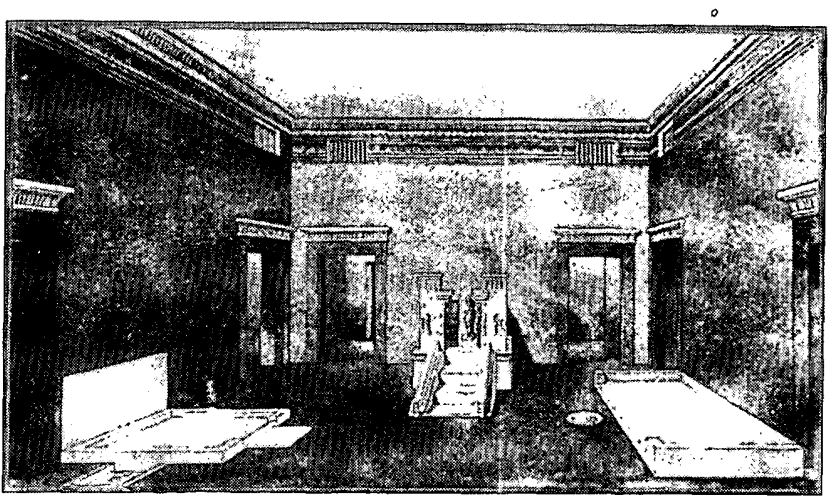

図 10 神官パアネヘシィの公㿟：クラークによる復原图 Frankfort: "Preliminary Report on the Excavations at Tell el-'Amarna, 1926-7", Journal of Egyptian Archaeology 13, pl. XLVII-1 より 
に及ぶスギ材が輸入されたことが知られている22。従って、こうした 特別に長い木材の調達が可能で、天井材の自重をできる限り軽減すれ ばある程度長いスパンに柱を用いずに 1 本の木の梁を渡して屋根をか けることができたと考えられなくない。都市域の典型的なアマルナ型 住宅の場合とは異なって、2 階に居住空間を持たない住宅Aならば、 天井を柱で支持して頑強にする必要性が少なかったとも推測される。 すなわち、広間の奥側に備えられた主人のための格別に大きな石の台 座を強調して見せるために構造的な困難を伴いながらも柱を排除しよ うとした意欲的な試みがなされたと見做すことが可能であり、こちら の復原案の方が王宮内に築かれた建物としては魅力的で、より妥当な 解釈であろうと結論される。

\section{6. 結融}

マルカタ王宮内に残る 3 軒のアマルナ型住宅の初例は、基本的骨 格において都市アマルナに存在する典型的なアマルナ型住宅の平面構 成と合致するが、現地調查の結果を基にして細部にも目を向けると、 玄関ポーチや、柱、壁倠装飾など全般的に欠如している要素が多いこ とが分かった。とりわけ住宅 Aの中央の主要広間は特異な様相を示 しており、残存する痕跡についての考察から、広間の南壁に接して玉 座に匹敵する大きさの石製の台座が備えられていたことを明らかにし た。スパンが広いこの部屋には柱の痕跡が全く見られず、その有無は 判然としないが、可能性としては 2 案あり、柱が存在したとすれば、 台座の両端に柱礎石が載せられたと考えられ、あるいは、より妥当な 案として、王宮内の施設として格別な計らいがなされたという仮定も 含めれば、大きな台座を強調して見せるために意図的に柱が排除さ れ、特別に長い木材を調達して屋根がかけ渡されたと結論した。この 住宅はアマルナ型住宅の初期の姿を伝える重要な遺構であり、いまだ 精査がおこなわれていない住宅B、Cについてなど、今後の調査が待 たれる。

\section{註・参考文献}

1. 遠藤孝治「アマルナ型住宅の初例に関する考祭 : 古代エジプト・アマルナ 型住宅に関する建築学的考察 1 小、『日本建築学会計面系諭文報告集』、第 560 号（2002年10月）、283-288頁。

2. エジプトにおける住宅形式の伝統的な流れに添うものだという見方がなさ れる一方で (F. Arnold: "Study of Egyptian Domestic Buildings", Varia Aegyptiaca 5 (1989), pp. 78-81)、新王国時代の王宮建築の様式を意図的に採り入れた独自の 住宅形式であるという見解がある (P. Lacovara: The New Kingdom Royal City (London and New York 1997), p. 60)。アマルナ型住宅に関する研究史は、上述の拙 稿の中で部述しているので、本稿の前提として参照されたい。

3. 1985〜1988年におこなわれたマルカタ王宮での発掘調查に関しては、中 川武・西本真一編『マルカタ王宮の研究』、中央公論美術出版（1993年 2月） がすでに刊行されている。本稿で取り扱う王宮内のアマルナ型住宅については、 同舞の 207-209頁において、後藤久氏 (日本女子大学住居学科教授)により概 要が報告されている。この後も往時の装飾画を復原するための整理作業が継続 しておこなわれており、その主な成果は、西本真一「エジプト・マルカタ王宮 「王の寝室」の天井画」、『オリエント\&、第 44巻第 1 号 (2001 作 9月)、76-94 頁、西本真一『古代エジプト・マルカタ王宮の復原研究タ、早稻由大学理工学 部博士学位請求論文（2002 年 2 月）が代表に挙げられる。

4. 現地視察の湖許可を頂いた早稲田大学エジプト学研究所所長・吉村作治教 授、並びに同大学文学部助教授・近藤二郎先生、また同大学理工学部建築史研 究室の所藏資料を利用させて頂いた理工学部教授・中川武先生に感謝申し上げ る。現地での図面作成作業は、同大学理工学部助教授・西本真一先生の指導の 下、柏木裕之氏 (現・早稲田大学エジプト学研究所客員請師)、佐藤桂（旧姓： 井上）氏、横山拓氏の助力を得た。また、本稿の執篗において西本真一先生に は多々の貴重な郝指摘を頂いた。記して感謝申し上げたい。
5. 本稿住、拙稿 “Amama-type Houses at the Malqata Palace-city”, The Journal of the Society for the Study of Egyptian Antiquities 25 (1998) pp. 23-37の後半部分、「マ ルカタ王宮内のアマルナ型住宅について、『日本西アジア考古学会第 6 回総会・ 大会要旨集』(2001年6月)、35-39頁、「マルカタ王宮内にあるアマルナ型住 宅Aの中央広間に関する復原的考察 : マルカ夕王宮に関する研究46小、P日本建 築学会大会学術講演校概集 (北陸) \&、F-2、631-632 頁で発表した内容を基に 大幅な加筆修正をおこなったものである。

6. 都书アマルナに残存する比較的小さな住宅M50.8も住宅の北側にステップ だけの玄閣を持つ間素な造りであるが、マルカタ王宮内の住宅A と同規模の住 宅頲構では、必ず独立した玄関ポーチが付属される。See L. Borchardt and H Ricke: Die Wohnhäuser in Tell el-Amarna (Berlin 1980), Plan 95.

7. 外部からの見通しを遮断するというだけでなく、激しい陽光と砂暨の流入 を抑制する意図があったと思われる。Cf. P. T. Crocker: “Status Symbols in the Architecture of el- 'Amarna", The Journal of Egyptian Archaeology 71 (1985), pp. 57-58. 古代エジプト建築に詳しいアイグナーもまた、末期王朝時代の墳墓の考察の中 で、鉤型の導入経路について言及している。Cf. D. Eigner: Die monumentalen Grabbauten der Spätzeit in der Thebanischen Nekropole (Wien 1984), p. 115.

8. 小さな円形の炉は、例えば本稿第 4 節で言及する幸相ナクトの住宅におい て、主人の台座の手前に見られる(図 $8-2$ 参照)。

9. A. Endruweit: Städtischer Wohnbau in Ägypten: Klimagerechte Lehmarchitektur in Amarna (Berlin 1994), pp. 29-45.

10. 典型的なアマルナ型住宅の平面構成についての詳絒は、拙稿「アマルナ 型住宅の初例に関する考察 : 古代エジプト・アマルナ型住宅に関する建築学的 考察 11、『日本建築学会計画系論文報告集』、第 560 号 (2002 年 10 月)、284 頁を参照されたい。

11. 住宅内から出士したパピルス文畫の封をするための泥の目章を基に 3 人の 高官のための施設であったと推定されているが、詳紐は明らかではない。Cf. W. C. Hayes: "Inscriptions from the Palace of Amenhotep III", Journal of Near Eastern Studies 10 (1951), p. 177

12. 近年のアマルナ遺跡におけるイギリス調查隊の発招成果からはアマルナ 型住宅の 2 階部分が居住空間として広く多目的に利用されたことが指摘されて いる。Cf. B. J. Kemp: "Site Formation Processes and the Reconstruction of House P46.33”, in Amarna Reports VI (London 1995), pp. 152-158. 與型的なアマルナ型住 宅で柱が多用されている点は、こうした 2 階空間の充実と関係があると思われ る。

13. 此較的規模の小さな住宅では、広間の中央に 1 本だけ柱が立てられるこ ともある。また、アマルナの大きめな住宅の 049.1 は、図面からだけでは柱が 存在しないように見えるが、報告書の文中で柱の痕跡が残っていたと記述され ている。Borchardt and Ricke: op. cit., p. 239, Plan 74: O49.1.

14. Cf. T. E. Peet and C. L. Woolley: The City of Akhenaten 1 (London 1923), pp. 37. 50, Pls. HII-V

15. J. D. S. Pendlebury: The City of Akhenaten III, text \& plates 2 vols. (London 1951), pp. 26-27, Pls. XI-XII.

16. Ibid., pp. 22-25, PI. X

17. Robb de P. Tytus: A Preliminary Report on the Re-excavations of the Palace of Amenhetep III (New York 1903, reprint, San Antonio 1994), p. 17.

18. U. Hölscher: The Excavation of Medinet Habu III (Chicago 1951); p. 55. また、 古代エジブトの玉座に関する代表的な文献としては、K. P. Kuhlman: Der Thron im alten Ägypten: Untersuchungen zu Semantik, Ikonographie und Symbolik eines Herrschaftszeichens. Abhandlungen des Deutschen Archaeologischen Instituts Kairo, Ägyptologische Reihe 10 (Glueckstadt 1977) が挙げられる。

19. F. Arnold: "Houses", in D. B. Redford ed.: The Oxford Encyclopedia of Ancient Egypt 2 (Oxford 2001), pp. 122-127.

20. 明らかなところでは、例えばマルカタ王宮内の「王の演室」では、約 $4.6 \mathrm{~m}$ のスパンに柱を全く立てずに屋根がかけられていた。中川武・西本真一編『マ ルカタ王宮の研究タ、148 頁参照。

21. 後に刊行された調查報告茾の中でペンドルベリィは、この復原図におけ る天井際のコーニス装飾が存在せず、ピンク色に攀られた梁が天井に架け渡さ れていたと訂正をしている。Cf. Pendlebury: op. cit., p. 26.

22. S. R. K. Glanville: "Records of the Time of Tuthmosis III: Papyrus British Museum 10056", Zeitschrift für Ägyptische Sprache und Altertumskunde Bd.66 (1930), Part I, pp. 105-121; Bd.68 (1932), Part II, pp. 7-41.

（2003年 6 月10日原稿受理，2003年11月 7 日採用決定） 